\title{
XPS studies on the Mo oxide-based coatings electrodeposited from highly saturated acetate bath
}

\author{
Edita Vernickaite $\dot{e}^{1}$, \\ Martynas Lelis², \\ Natalia Tsyntsaru ${ }^{1,3}$, \\ Vidas Pakštas ${ }^{4,5}$, \\ Henrikas Cesiulis ${ }^{1,4}$ \\ ${ }^{1}$ Department of Physical Chemistry, \\ Vilnius University, \\ 24 Naugarduko Street, \\ 03225 Vilnius, Lithuania \\ ${ }^{2}$ Lithuanian Energy Institute, \\ 3 Breslaujos Street, \\ 44403 Kaunas, Lithuania \\ ${ }^{3}$ Institute of Applied Physics, \\ 5 Academiei Street, \\ MD-2028 Chisinau, Moldova \\ ${ }^{4}$ JSC Elektronikos Perdirbimo Technologijos, \\ 45-79 Medeinos Street, \\ 06140 Vilnius, Lithuania \\ ${ }^{5}$ Center for Physical Sciences \\ and Technology, \\ 3 Sauletekio Avenue, \\ 10257 Vilnius, Lithuania
}

The possibility to use highly saturated acetate bath to electrodeposit the mixed-phase materials containing Mo oxides has been investigated. The XRD characterization revealed that the as-deposited coatings are amorphous and consist only of $\mathrm{MoO}_{2}$ and $\mathrm{MoO}_{3}$ phases without traces of metallic Mo phase. This statement has been supported by XPS measurements, which reveal the presence of three different molybdenum oxidations states in electrodeposits: $\mathrm{Mo}^{4+}, \mathrm{Mo}^{5+}$ and $\mathrm{Mo}^{6+}$. It was found that the $\mathrm{Mo}^{6+}$ state prevails with $41 \%$ of total contribution, whilst $\mathrm{Mo}^{5+}$ and $\mathrm{Mo}^{4+}$ contribute to 28 and $31 \%$, respectively. The deposits retain an amorphous structure up to $800^{\circ} \mathrm{C}$; while molybdenum at this temperature is predominantly oxidized to the $\mathrm{Mo}^{6+}$ state $(91 \%)$. These results, coupled to those of SEM and EDS, revealed that concentrated acetate bath could be used mainly for the formation of the mixed valence molybdenum oxide film unlike to the deposition of the metallic Mo phase.

Keywords: X-ray photoelectron spectroscopy, molybdenum, molybdenum oxides, electrodeposition, $\mathrm{X}$-ray diffraction

\section{INTRODUCTION}

Molybdenum oxide $\left(\mathrm{MoO}_{\mathrm{x}}\right)$ thin films exhibit interesting structural, chemical, electrical and optical properties [1, 22], and it makes them attractive to use them in a new type of technological devices. Since molybdenum has the oxidation states rang-

*Corresponding author. Email: henrikas.cesiulis@chf.vu.lt ing from +2 to +6 , a variety of its oxide compounds exist. The most important and commonly found are molybdenum trioxide and molybdenum dioxide. Particularly, $\mathrm{MoO}_{3}$ films have an important application in gas sensors [3], energy storage [4], optical switching devices [5] and smart windows [6]. Meanwhile, $\mathrm{MoO}_{2}$ can be potentially used as an anode material for the solid oxide fuel cells [ []. 
Thus, an accurate elemental oxidation state determination for the outer surface of a complex molybdenum oxide material is of crucial importance in many science and engineering disciplines, including chemistry, fundamental and applied surface science, catalysis, semiconductors and many others. X-ray photoelectron spectroscopy (XPS) is the primary tool used for this purpose. XPS has been clearly useful in monitoring changes in elemental oxidation states and in stoichiometry during various processes.

Previously, XPS analysis has been used to elucidate the composition of the molybdenum oxide films grown by heating molybdenum metal in the air [8, 9], using pulsed-laser deposition and sputtering techniques [10]. Generally, the Mo oxide films prepared by mentioned techniques are predominantly in the $\mathrm{Mo}^{6+}$ state [11]. Also in some cases, a small quantity of $\mathrm{Mo}^{5+}$ at the top oxide film surface can be observed due to the exposure of films to the atmosphere [10]. However, the electrodeposition of Mo oxides from an aqueous solution is an advantageous method since it offers an easy control over the thickness, morphology and extent of oxidation. Moreover, water-based electrolysis is a costeffective and environment-friendly alternative than those requiring the volatile and/or inflammable solvents [12]. In the light of these advantages, $\mathrm{MoO}_{\mathrm{x}}$ thin films have been deposited from aqueous peroxo-polymolybdate [13], sodium molybdate [14] and ammonium-heptamolybdate [15] solutions. In this case, the electrodeposited films consist of mixed valence oxides containing $\mathrm{Mo}^{+4}, \mathrm{Mo}^{+5}$ and $\mathrm{Mo}^{+6}[16-18]$. However, the literature review indicates that the catalytic properties and composition of electrolytic molybdenum oxide films are closely related to electrolyte composition, electrolyte $\mathrm{pH}$ and applied potential/current density.

It was found that the catalytic activity decreases in the following sequence: $\mathrm{MoO}_{2}>\mathrm{MoO}_{3}>\mathrm{Mo}[19]$. Such findings provide motivation for the development of a simple electrodeposition procedure for preparation of more active metallic molybdenum films that would be combined with its oxides in a synergetic manner to yield a surface which is more active than each of the components separately. On the other hand, metallic molybdenum deposition from aqueous electrolytes is rather a failure, which can be attributed to the rapid uptake of oxygen by Mo and the formation of a mix- ture of polyvalent molybdenum oxides and/or hydroxides on the cathode during electrodeposition [20]. Nevertheless, molybdenum electrodeposition from aqueous saturated acetate baths is discussed [21-23]. It was reported that Mo coatings obtained from a saturated acetate salt solution at very high current densities (200-400 $\mathrm{mA} \mathrm{cm}^{-2}$ ) are characterized by an amorphous structure and a low oxygen content on the top of the surface [22]. It was suggested that hydrogen which discharges simultaneously via water electrolysis under the mentioned conditions the cathode accelerates the molybdate ions reduction to metallic Mo in the presence of a high concentration of acetate ions.

The main aims of this work are (i) to investigate the possibility to electrodeposit the coating composed of mixed-valence molybdenum oxides and possibly of metallic Mo, and (ii) to study the electrodeposited coating using the XPS technique.

\section{EXPERIMENTAL}

\section{Electrodeposition}

The mixed-phase materials consisting of metallic Mo and its oxides coatings were attempted to electrodeposit from an aqueous solution consisting of ammonium heptamolybdate $\left(\left(\mathrm{NH}_{4}\right)_{2} \mathrm{MoO}_{4}-0.0034 \mathrm{M}\right)$, a high concentration of ammonium acetate $\left(\mathrm{CH}_{3} \mathrm{CO}_{2} \mathrm{NH}_{4}-8.6 \mathrm{M}\right)$ and potassium acetate $\left(\mathrm{CH}_{3} \mathrm{CO}_{2} \mathrm{~K}-0.68 \mathrm{M}\right)(\mathrm{pH}$ $7.0 \pm 0.1$, similar to those described in [21]. The deposition of the coating was carried out under a galvanostatic mode at a cathodic current density of $350 \mathrm{~mA} \mathrm{~cm}^{-2}$. It was reported that the electrodeposition of Mo does not depend on the cathode material and stirring rate. However, in [23] it was investigated that when the stirring rate is lower than $400 \mathrm{rpm}$, molybdenum oxide is deposited on the substrate surface due to the increased viscosity of the electrolyte. Thus, in the present work the coatings were obtained on a cylindrical $\mathrm{Cu}$ electrode of $1 \mathrm{~cm}^{2}$ rotated at $800 \mathrm{rpm}$. The $\mathrm{Cu}$ substrate preparation consisted of chemical degreasing, washing and cleaning in an ultrasonic bath for 6-7 $\mathrm{min}$ and etching in $\mathrm{HNO}_{3}: \mathrm{CH}_{3} \mathrm{COOH}: \mathrm{H}_{3} \mathrm{PO}_{4}(1: 1: 1)$ solution at $60^{\circ} \mathrm{C}$ temperature. The saturated $\mathrm{Ag} / \mathrm{AgCl}$ electrode was used as a reference electrode and all potentials presented in the study are referred to this 
electrode, and the platinum sheet $(3 \times 7 \mathrm{~cm})$ was served as a counter electrode.

\section{Morphological and structural investigation}

The surface morphology and chemical composition of the obtained coatings were investigated using scanning electron microscopy (SEM: Hitachi TM3000) equipped with energy dispersive $\mathrm{X}$-ay spectroscopy (EDS) at accelerating voltage of $20 \mathrm{kV}$. The structure of the films was analysed by the Xray diffraction method (XRD: Rigaku MiniFlex II). The XRD patterns were produced with $\mathrm{Cu} \mathrm{Ka}$ radiation (1.5406 $\AA$ ) in the $2 \theta$ scanning mode from 20 to $100^{\circ}$ with a step of $0.01^{\circ}$. The heat treatment of the coatings was performed by using an MRI temperature camera (MRI TC) with a Pt-Rh heating element. The samples were annealed at a heating rate of $10^{\circ} \mathrm{C} / \mathrm{min}$ up to $800^{\circ} \mathrm{C}$, which was maintained for $5 \mathrm{~h}$ in order to achieve stable conditions. Then the deposits were cooled down to the room temperature and XRD measurements were performed under the same conditions that were described above. For the analysis of the coatings surfaces $\mathrm{X}$-ray photoelectron spectroscopy was performed by using an ULVAC-PHI Versaprobe 5000 device with a monochromatic $\mathrm{Al} \mathrm{Ka}(1486.6 \mathrm{eV})$ source and a pass energy of $23.5 \mathrm{eV}$. The XPS system was equipped with an $\mathrm{Ar}^{+}$ion source that was used to remove surface material for cleaning of the samples. The spectrometer energy scale was calibrated by using two reference points $\left(\mathrm{Au} 4 \mathrm{f}_{7 / 2}\right.$ at $84 \mathrm{eV}$ and $\mathrm{Cu} 2 \mathrm{p}_{3 / 2}$ at $932.7 \mathrm{eV}$ ). Sample charging was compensated using the dual neutralization system consisting of a low energy electron beam and a ion beam and fixing an adventitious carbon $\mathrm{C} 1 \mathrm{~s}$ peak at $284.8 \mathrm{eV}$ in accordance with the previous investigation results 23,25$]$. The spectra were processed and fitted by the Multipak software.

\section{RESULTS AND DISCUSSION}

Following the suggested procedure [21], the electrodeposition of Mo-based coating was carried out from a highly saturated acetate bath at $-350 \mathrm{~mA} \mathrm{~cm}^{-2}$ for $14 \mathrm{~h}$ in order to deposit the coating thick enough for instrumental analysis. As the current started flowing through the system, the cathode was covered by a light grey layer and an intense instantaneous foaming of the solution due to the enormous hydrogen evolution has been observed. Moreover, black precipitate was noticed in the plating bath after electrolysis probably because of the conversion of $\mathrm{MoO}_{4}^{2-}$ to $\mathrm{MoO}_{2}$. Furthermore, the SEM images show that the deposit is not uniform and the $\mathrm{Cu}$ substrate is not covered continuously; various sizes nodules and multiple cracks were detected (Fig. 1a, b). Meanwhile, a more detailed view at a higher magnification revealed a fine and granular surface morphology of the coating (Fig. 1 c).

The EDS spectra of the as-deposited coating indicate the presence of a high amount of oxygen (67.4 at.\%). Moreover, the XRD pattern shows that under the applied deposition conditions one broad peak at $2 \Theta \approx 37^{\circ}$ is present (Fig. 2a). Based on PDF cards Nos. 00-005-0506 and 00-005-0452, the following peaks can be attributed to $\mathrm{MoO}_{3}(101)$ at $\sim 33^{\circ}, \mathrm{MoO}_{2}(200)$ and $\mathrm{MoO}_{2}(111)$ at $\sim 37^{\circ}$.

It is notable that no diffraction peaks of metallic Mo or other crystalline phases were found, except those that match the spectral lines of the $\mathrm{Cu}$ substrate. Taking into account an incredibly high amount of oxygen and knowing that Mo exists in a variety of oxidation states, the as-deposited coatings were annealed at a high temperature of $800^{\circ} \mathrm{C}$ in air atmosphere in order to identify the crystalline oxide phases.

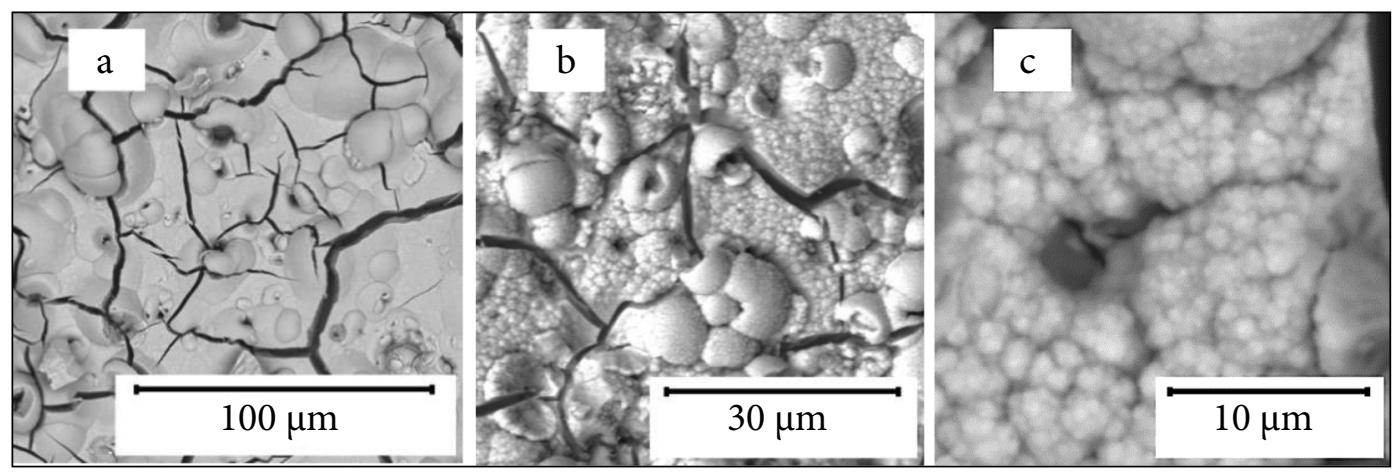

Fig. 1. SEM images of the electrodeposited coating at different magnifications: (a) $\times 800$, (b) $\times 3000,(c) \times 6000$ 


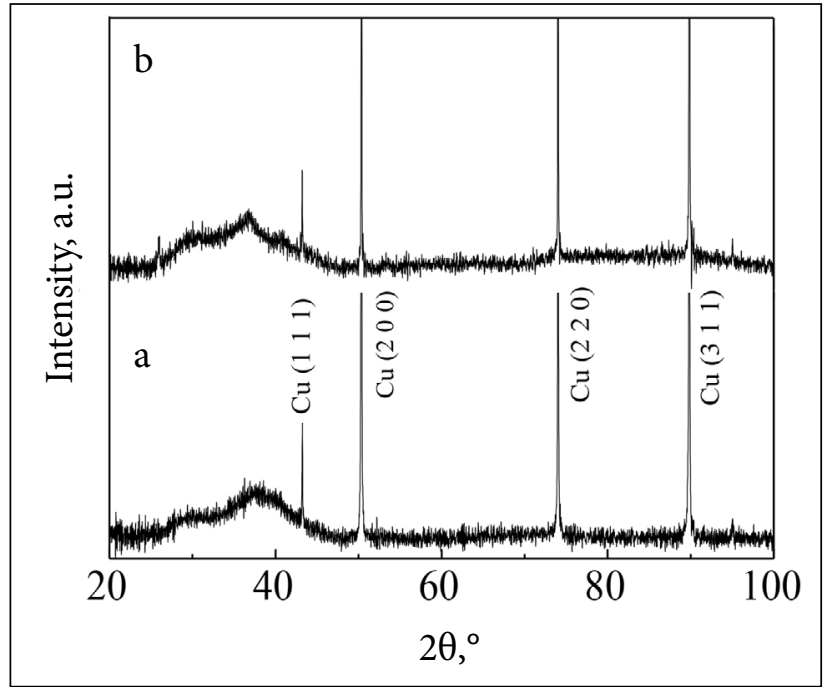

Fig. 2. XRD pattern of the coating deposited on copper electrode at $350 \mathrm{~mA} \mathrm{~cm}^{-2}$ and $30^{\circ} \mathrm{C}$ : as-deposited coating (a) and after heat treatment at $800^{\circ} \mathrm{C}$ for $5 \mathrm{~h}$ in air atmosphere (b)

As it was reported, the thermally induced changes in the internal structure of Mo deposit start at $700^{\circ} \mathrm{C}$ temperature and new phases assigned to (110), (200), (211) and (220) reflections of Mo appear. At the higher temperature, $\mathrm{T}>800^{\circ} \mathrm{C}$, additional peaks of $\mathrm{MoO}_{2}$ and $\mathrm{MoO}_{3}$ start forming [22]. However in our work, as it can be seen from Fig. 2b, even after heat treatment at $800^{\circ} \mathrm{C}$ in the air atmosphere for $5 \mathrm{~h}$, the Mo structure retains an 'amorphous-like' structure and similar to the as-deposited coating crystalline phase peaks are visible only due to the $\mathrm{Cu}$ substrate.

In addition, XPS analysis was performed to identify the composition of as-deposited and heattreated Mo-based films and the characterization was focused on the bonding of Mo to the oxygen. It should be noted that due to the complexity of the Mo $3 \mathrm{~d}$ spectra, quite wide ranges (i.e. $0.8-1.0 \mathrm{eV}$ ) of the binding energies for the same Mo oxides are provided in the literature and in various studies they are different even for the same oxide [25-28]. The importance of the critical assessment and reliance on the published XPS data is clearly demonstrated in Ref. [24] that repeats an undisputedly erroneous interpretation of the Mo $3 \mathrm{~d}$ peak provided in [22]. In the latter work, without any fitting, the authors mark three apexes of the observed multicomponent Mo $3 \mathrm{~d}$ peak as $\mathrm{Mo}^{0}$ $3 \mathrm{~d}_{5 / 2}$ (at $228.8 \mathrm{eV}$ ), Mo(III) $3 \mathrm{~d}_{3 / 2}$ (at $232.1 \mathrm{eV}$ ) and $\mathrm{Mo}(\mathrm{VI}) 3 \mathrm{~d}_{3 / 2}$ (at $235.5 \mathrm{eV}$ ). The generally accepted

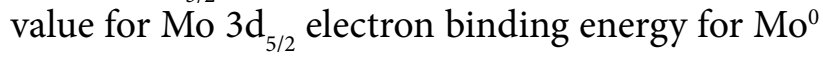

metal is $228.0 \mathrm{eV}$ and a significantly higher value of $228.8 \mathrm{eV}$ is probably assigned to the non-careful interpretation of the results published in [21], where authors also report a similarly high $\mathrm{Mo}^{0} 3 \mathrm{~d}_{5 / 2}$ value, but provide comments that it is overestimated by $0.8 \mathrm{eV}$ due to the uncompensated charging.

By fitting current Mo 3d XPS data, no components near to the $228 \mathrm{eV}$ binding energy were observed and it was concluded that there was no $\mathrm{Mo}^{0}$ metallic phase in the samples. Whereas for the curve fitting of the oxidized Mo forms the model proposed in [29] was used suggesting the use of three oxidation states of $\mathrm{Mo}$, i.e. $\mathrm{Mo}^{6+}, \mathrm{Mo}^{5+}$ and $\mathrm{Mo}^{4+}$ (from the highest to the lowest binding energy components) for corresponding components and disregarding the possible energy shifts in the discussion. Accordingly, in this study, at first the as-deposited Mo coating spectra were fitted using three Mo $3 \mathrm{~d}_{5 / 2}$ components at 229, 230.5 and $232.1 \mathrm{eV}$ that correspond to the oxidation states of $\mathrm{Mo}^{4+}, \mathrm{Mo}^{5+}$ and $\mathrm{Mo}^{6+}$ (Fig. 3). Also, higher energy

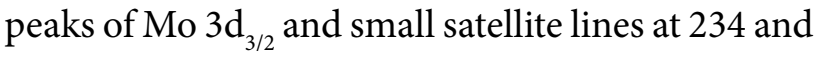
$237 \mathrm{eV}$ can be seen.

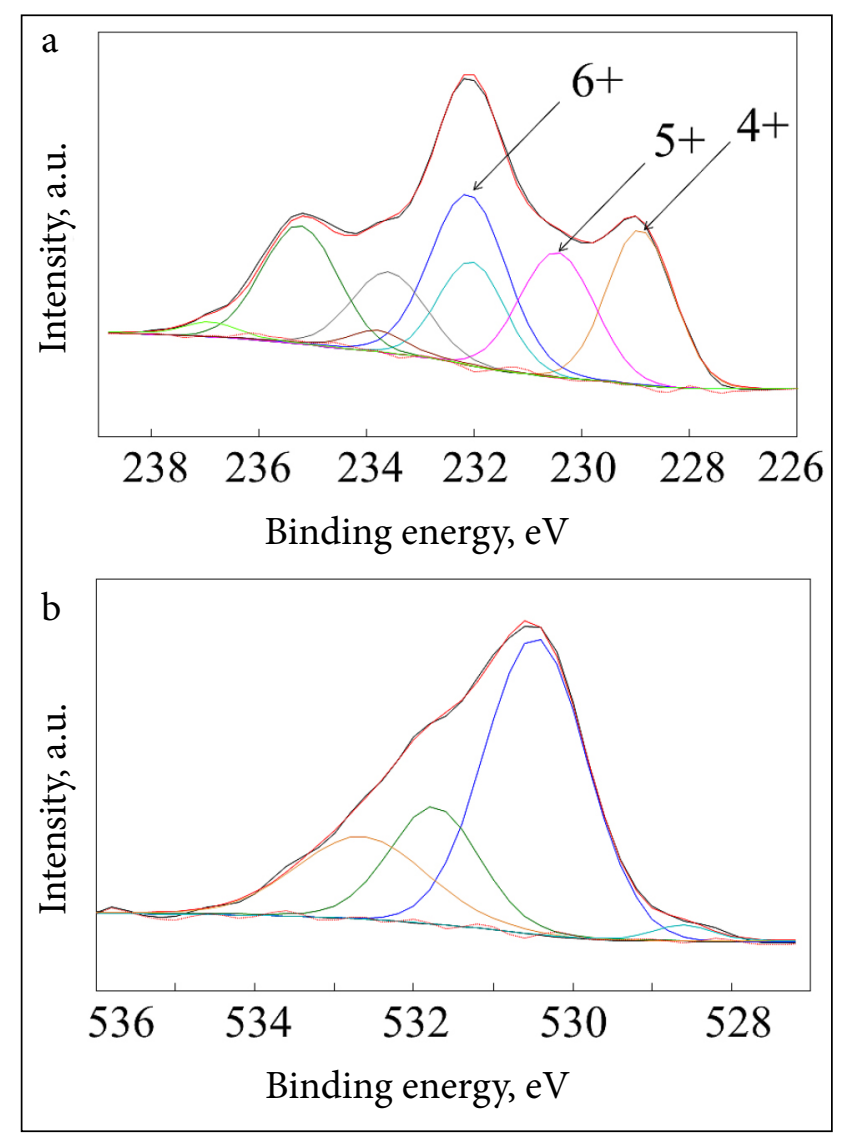

Fig. 3. Mo 3d and O 1s XPS spectra of as deposited coating samples (coloured online) 
The XPS data fitting reveals that the deposited coating comprises species corresponding to various Mo oxidation states with different percentage. Namely, $\mathrm{Mo}^{4+}, \mathrm{Mo}^{5+}$ and $\mathrm{Mo}^{6+}$ species are present in the following percentage: $31, \sim 28$ and $\sim 41 \%$, respectively.

After an exposure of the samples to the air for 4 months (see Fig. 4), the amount of $\mathrm{Mo}^{4+}$ component was significantly lower (around 21\%) and the contribution from $\mathrm{Mo}^{6+}$ increased up to $49 \%$. Such results indicate that lower valent state Mo is predominantly oxidized to $\mathrm{MoO}_{3}$. While the $\mathrm{Mo}^{5+}$ percentage remained stable (around 28-29\%) and possibly could be considered as an intermediate state during the $\mathrm{Mo}^{4+}$ transition to $\mathrm{Mo}^{6+}$. Nevertheless, it is presumed that $\sim 10 \%$ of potassium detected in the sample is attributed to the organic substances adsorbed from electrolyte and corresponds to $\mathrm{K}_{2} \mathrm{MoO}_{4}$ compound, which could contribute to the main peak at $232.1 \mathrm{eV}$. Thus, it should be concluded that not all oxidation state of $\mathrm{Mo}^{6+}$ is related to the formation of $\mathrm{MoO}_{3}$ phase. This is due to overlapping of the binding energies of $\mathrm{MoO}_{3}$ and $\mathrm{K}_{2} \mathrm{MoO}_{4}$ compounds (the difference is just around $0.1 \mathrm{eV}$ [30]).

Figure 5 indicates that after the thermal treatment at $800^{\circ} \mathrm{C}$ molybdenum is predominantly oxidized to the $\mathrm{Mo}^{6+}$ state. Its fraction is $91 \%$ for the as-deposited sample and $84 \%$ for the same sample after exposure for 4 months in the air atmosphere. Interestingly, the $\mathrm{Mo}^{4+}$ and $\mathrm{Mo}^{5+}$ peaks detected in the as-deposited films appear very similar to those determined in the XPS spectra of the same samples previously exposed to the atmosphere for 4 months.

Meanwhile, after keeping the annealed Mo coating samples up to 4 months in atmospheric air, only one additional Mo $3 \mathrm{~d}_{5 / 2}$ peak is visible at 230.8-231.1 eV. It can be assumed that this binding energy is attributed to the +5 oxidation state of $\mathrm{Mo}\left(\mathrm{MoO}_{\mathrm{x}}\right)$. On the other hand, water vapour can be absorbed onto the surface in air, thus explaining the possible formation of $\mathrm{Mo}(\mathrm{OH})_{\mathrm{x}} / \mathrm{Mo}$ type hydroxides, in agreement with previous studies [29].

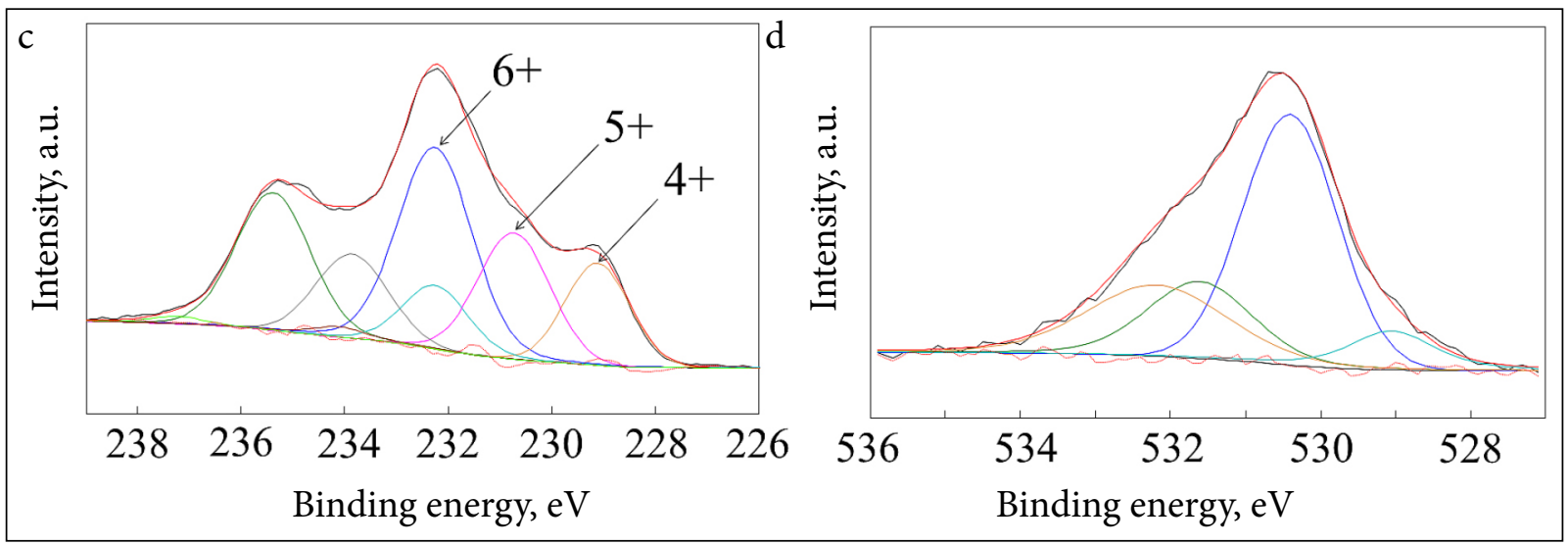

Fig. 4. Mo $3 \mathrm{~d}$ and $\mathrm{O} 1 \mathrm{~S}$ XPS spectra of as deposited coating samples after 4 months exposure to the atmosphere (coloured online)

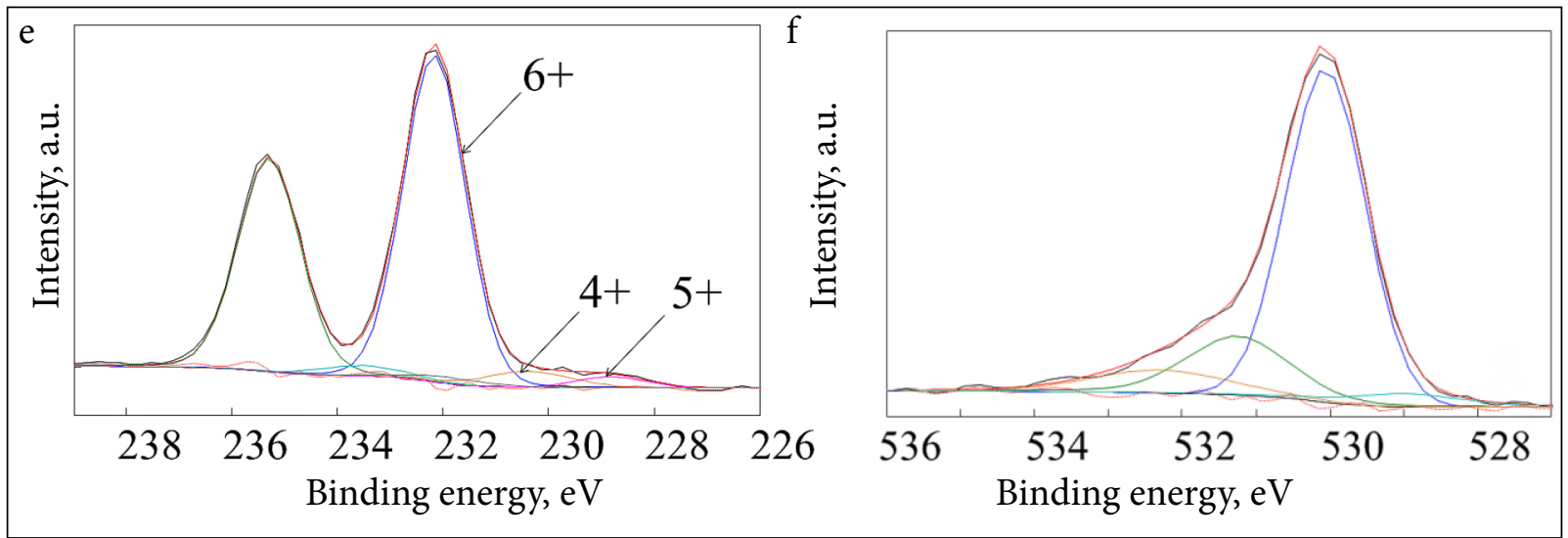

Fig. 5. Mo 3d and O 1s XPS spectra of annealed coating samples (coloured online) 
Other authors reported that the binding energies for the $\mathrm{O} 1 \mathrm{~s}$ peaks of $\mathrm{MoO}_{2}$ and $\mathrm{MoO}_{3}$ compounds differ only by $0.2 \mathrm{eV}$ and have almost identical full width at half maximum (FWHM) [31]. Supporting this finding, an interpretation determining the $\mathrm{MoO}_{2}$ and $\mathrm{MoO}_{3}$ lines in the XPS spectra is quite complicated. Nevertheless, according to the given Mo $3 \mathrm{~d}$ data, general assumptions can be proposed.

In the recent study, no significant changes were observed in $\mathrm{O}$ 1s spectra and in all cases they are dominant by one peak at about $530.3 \pm 0.1 \mathrm{eV}$ which becomes more intense after thermal treatment, thus corresponding to the oxidation state $\mathrm{Mo}^{6+}$. Contrary to the Mo 3d spectra, in this case other spectral components do not disappear. Most likely, the peak at $532.5 \mathrm{eV}$ is attributed to organic contamination and absorbed water molecules, whilst the peak at $531.2 \mathrm{eV}$ corresponds to the $\mathrm{MoO}_{3}$ phase and the dominant peak is characteristic of the overlapped $\mathrm{MoO}_{2}$ and $\mathrm{K}_{2} \mathrm{MoO}_{4}$ lines. Then after heat treatment, we can see that the dominant peak is more expressed (due to crystallization of $\mathrm{K}_{2} \mathrm{MoO}_{4}$ ) and narrowed (only one line forms from two overlapped peaks), meanwhile the $\mathrm{MoO}_{3}$ component is practically unchanged. The weak peak at the binding energy of approximately $529 \mathrm{eV}$ can be related to defective Mo oxide, intercalated water molecules or some kind of organic compound residuals.

\section{CONCLUSIONS}

1. The amorphous-like mixed valence molybdenum oxide films were electrodeposited from a highly saturated acetate electrolyte under the galvanostatic mode. The XRD analysis showed that the deposits consisted only of a mixture of $\mathrm{MoO}_{2}$ and $\mathrm{MoO}_{3}$ phases without any reflection of the $\mathrm{Mo}^{0}$ phase.

2. The presence of Mo oxides was confirmed by XPS analysis. The spectrum exhibited the characteristic Mo $3 \mathrm{~d}_{5 / 2}$ peaks at 229, 230.5 and $232.1 \mathrm{eV}$ that correspond to the oxidation states of $\mathrm{Mo}^{4+}, \mathrm{Mo}^{5+}$ and $\mathrm{Mo}^{6+}$ in the following percentages: 31, 28 and $41 \%$.

3. After the annealing at $800^{\circ} \mathrm{C}$, the films remained amorphous-like; however, molybdenum was predominantly oxidized to the $\mathrm{Mo}^{6+}$ state (91\%). No peak at the bonding energy of $228 \mathrm{eV}$ which is characteristic of the Mo metallic phase was observed.
4. This suggests that the electrodeposition from the concentrated acetate solution can be used for the synthesis of a mixture of $\mathrm{MoO}_{3}$ and $\mathrm{MoO}_{2}$, but not for the metallic molybdenum phase, as it was reported by previous authors. Nevertheless, the use of such coatings as catalysts in many reactions with the participation of hydrogen or oxygen could be the area of interest for researchers.

\section{ACKNOWLEDGEMENTS}

This research has received funding from the Horizon 2020 Research and Innovation Program under MSCA-RISE-2017 (No. 778357) and from the Research Council of Lithuania Project (No. 09.3.3-LMT-K-712-08-0003).

Received 1 July 2020 Accepted 11 August 2020

\section{References}

1. N. Miyata, T. Suzuki, R. Ohyama, Thin Solid Films, 281-282, 218 (1996).

2. T. Ivanova, K. Gesheva, A. Szekeres, J. Solid State Electrochem., 7, 21 (2002).

3. H. M. M. M. Arachchige, E. Comini, D. Zappa, G. Sberveglieri, Proceedings, 1, 449 (2017).

4. F. Miao, W. Wu, Q. Li, R. Miao, B. Tao, Int. J. Electrochem. Sci., 12, 12060 (2017).

5. A. L. Pergament, V. P. Malinenko, L. A. Aleshina, E. L. Kazakova, N. A. Kuldin, J. Exp. Phys., 2014, 1 (2014).

6. T. Ivanova, K. Gesheva, A. Szekeres, J. Solid State Electrochem., 7, 21 (2002).

7. B. W. Kwon, C. Ellefson, J. Breit, J. Kim, M. Grant Norton, S. Ha, J. Power Sources, 243, 203 (2013).

8. P. A. Spevack, N. S. McIntyre, J. Phys. Chem., 97, 11020 (1993).

9. M. Arita, H. Kaji, T. Fujii, Y. Takahashi, Thin Solid Films, 520(14), 4762 (2012).

10. C. V. Ramana, V. V. Atuchin, L. D. Pokrovsky, U. Becker, C. M. Julien, J. Vac. Sci. Technol. A, 25(4), 1166 (2007).

11. C. V. Ramana, C. M. Julien, Chem. Phys. Lett., 428, 114 (2006).

12. W. Giurlani, G. Zangari, F. Gambinossi, et al., Coatings, 8(8), 260 (2018).

13. T. M. McEvoy, K. J. Stevenson, J. T. Hupp, X. Dang, Langmuir, 19, 4316 (2003).

14. D. D. Yao, J. Z. Ou, K. Latham, S. Zhuiykov, A. P. O'Mullane, K. Kalantar-Zadeh, Cryst. Growth Des., 12, 1865 (2012).

15. J. Tang, Y. Lu, B. Liu, P. Yang, Y. Huang, J. Kong, J. Solid State Electrochem., 7, 244 (2003). 
16. M. L. Petrova, M. S. Bojinov, I. H. Gadjov, Bulg. Chem. Commun., 43(1), 60 (2011).

17. D. Sinkeviciute, J. Baltrusaitis, N. Dukstiene, J. Solid State Electrochem., 15, 711 (2011).

18. O. G. Marin Flores, S. Ha, Appl. Catal. A Gen., 352, 124 (2009).

19. B. Bartlett, C. Soto, R. Wu, W. T. Tysoe, Catal. Lett., 21, 1 (1993).

20. V. V. Kuznetsov, K. E. Golyanin, Y. S. Ladygina, T. V. Pshenichkina, B. F. Lyakhov, K. V. Pokholok, Russ. J. Electrochem., 51, 748 (2015).

21. T. J. Morley, L. Penner, P. Schaffer, T. J. Ruth, F. Bénard, E. Asselin, Electrochem. Commun., 15, 78 (2012).

22. R. Syed, S. K. Ghosh, P. U. Sastry, G. Sharma, R. C. Hubli, J. K. Chakravartty, Surf. Coat. Tech., 261, 15 (2015).

23. A. Haftbaradaran, N. Parvini-Ahmadi, S. Yazdani, Surf. Coat. Tech., 324, 1 (2017).

24. N. D. Ivanova, S. V. Ivanov, E. I. Boldyrev, O. A. Stadnik, Prot. Met., 42, 354 (2006).

25. P. A. Spevack', N. S. McIntyre, J. Phys. Chem., 97, 11031 (1993).

26. D. O. Scanlon, G. W. Watson, D. J. Payne, G. R. Atkinson, R. G. Egdell, D. S. L. Law, J. Phys. Chem. C, 114, 4636 (2010).

27. H. Simchi, B. E. McCandless, T. Meng, J. H. Boyle, W. N. Shafarman, J. Appl. Phys., 114, 013503 (2013).

28. J. Baltrusaitis, B. Mendoza-Sanchez, V. Fernandez, et al., Appl. Surf. Sci., 326, 151 (2015).

29. O. Marin-Flores, L. Scudiero, S. Ha, Surf. Sci., 603, 2327 (2009).

30. NIST X-ray Photoelectron Spectroscopy Database, NIST Standard Reference Database 20, Version 4.1.
Data compiled and evaluated by A. V. Naumkin, A. Kraut-Vass, S. W. Gaarenstroom, C. J. Powell. Last Update to Data Content: 2012.

31. J. G. Choi, L. T. Thompson, Appl. Surf. Sci., 93, 143 (1996).

Edita Vernickaitė, Martynas Lelis, Natalia Tsyntsaru, Vidas Pakštas, Henrikas Cesiulis

\section{ELEKTROCHEMIŠKAI IŠ SOTAUS ACETATINIO ELEKTROLITO NUSODINTŲ MOLIBDENO OKSIDŲ PAGRINDU SUDARYTŲ DANGŲ TYRIMAS XPS METODU}

\section{Santrauka}

Darbe tiriamosios dangos, sudarytos iš mišrių molibdeno oksidų, buvo elektrochemiškai nusodinamos nekintančios srovès sąlygomis naudojant sotų acetatini elektrolitą. XRD analizè parodè, kad suformuotų „amorfinès“ prigimties dangų sudètyje nèra metalinio Mo, o jas sudaro tik $\mathrm{MoO}_{2}$ ir $\mathrm{MoO}_{3}$ fazès. Šios išvados buvo patvirtintos atlikus elektrochemiškai nusodintų dangu analizę XPS metodu, t. y. buvo nustatyti trys molibdeno oksidacijos laipsniai: $\mathrm{Mo}^{4+}, \mathrm{Mo}^{5+}$ ir $\mathrm{Mo}^{6+}$. Parodyta, kad šiame mišinyje $\mathrm{Mo}^{6+}$ sudaro $41 \%, \mathrm{o} \mathrm{Mo}^{5+}$ ir $\mathrm{Mo}^{4+}$ atitinkamai siekia $28 \%$ ir $31 \%$. Suformuotos dangos išlaiko stabilią „amorfinę" struktūrą kaitinant iki $800^{\circ} \mathrm{C}$; pasiekus minètą temperatūrą dangą sudaro daugiausiai $\mathrm{Mo}^{6+}(91 \%)$. Šie rezultatai kartu su SEM ir EDS tyrimais patvirtino, kad koncentruotas acetatinis elektrolitas gali būti naudojamas tik iš mišrių molibdeno oksidų sudarytai dangai gauti. Priešingai nei pateikiama mokslinèje literatūroje, metalinio molibdeno pèdsakų šiuo atveju nebuvo nustatyta. 